\title{
Implementation of Law No. 40 of 2009 concerning Youth Development Policy in Medan City
}

\author{
Piki Darma Kristian Pardede \\ Departement Urban and Regional Planning, Sekolah Pascasarjana, Universitas Sumatera Utara, Indonesia \\ Corresponding Author:pikipardede16@gmail.com
}

\section{Article Info}

Keyword:

Law Implementation; Youth Development;

City of Youth;

Dispora

\section{Kata Kunci:}

Dispora;

Implementasi Undang-

Undang; Kota Layak

Pemuda;

Pembangunan

kepemudaan.

\begin{abstract}
This research uses descriptive qualitative, by describing in detail the process of implementing policies related to the formulation of youth development policies. This research was conducted based on the Edward III policy implementation model, where Edward III assessed implementation policy with four variables in public policy namely Communication, Resources, dispositions atau attitudes and bureaucratic structure. It can be denied that the Medan Municipality Youth and Sports Agency has not yet implemented Law No. 40 of 2009 concerning optimal youth, especially in terms of giving attention to youth organizations in developing and empowering youth in their communities. In this study also found Law No. 40 of 2009 concerning Youth has not yet got a place in the Department of Youth and Sports (Dispora) Medan as a leading and strategic leader, in the development of youth development in Medan. This causes youth development by the Medan City Youth and Sports Agency to proceed slowly in directing youth development policies to realize Medan City to be a City of Youth (Kota Layak Pemuda) where Kota Layak Pemuda is one of the priority programs of the Ministry of Youth and Sports in improving the quality of youth standardization throughout Indonesia.
\end{abstract}

Abstrak: Penelitian ini menggunakan pendekatan deskriptif kualitatif, dengan mendeskripsikan secara detail proses implementasi kebijakan terkait dengan perumusan kebijakan pembangunan pemuda. Penelitian ini dianalisis berdasarkan model implementasi kebijakan Edward III, dimana Edward III menilai implementasi kebijakan dari kondisi abstrak dengan empat variabel dalam kebijakan publik yaitu Komunikasi, Sumber Daya, sikap dan struktur birokrasi. Dapat disimpulkan bahwa Dinas Pemuda dan Olahraga Kota Medan belum menerapkan UU No. 40 tahun 2009 tentang pemuda secara optimal, terutama dalam hal memberikan perhatian kepada organisasi pemuda dalam melakukan pengembangan dan pemberdayaan pemuda di komunitas mereka. Dalam penelitian ini juga ditemukan bahwa UU No. 40 tahun 2009 tentang Pemuda belum mendapat tempat pada Dinas Pemuda dan Olahraga (Dispora) kota Medan sebagai posisi terkemuka dan strategis, dalam kebijakan pengembangan pemuda di Medan. Hal ini menyebabkan pengembangan pemuda oleh Dinas Pemuda dan Olahraga Kota Medan berjalan lambat dalam mengarahkan kebijakan pembangunan pemuda untuk mewujudkan Kota Medan menjadi Kota Layak Pemuda (KLP) dimana KLP adalah salah satu program prioritas Kemenpora dalam meningkatkan kualitas standardisasi pemuda di seluruh Indonesia.

Article History: Received: 2020-05-22, Revised: 2020-06-13, Accepted: 2020-06-18

\section{INTRODUCTION}

The publication of Law No. 40 of 2009 concerning Youth, hereinafter referred to as the Youth Law, became a new hope point for Indonesian youth with their strength, spirit and 
orientation to be able to determine their position, role, authority over themselves. The hope is that young people can be socially and sovereignly powerful over politics which is the foundation of the development and democratization of the Indonesian nation. Also Law No. 20 of 2003 clarified that non-formal education involves life skills education, early childhood education, youth education, empowerment education for women, literacy education, technical training and work training, equity education, and other education aimed at improving the abilities of the students (Syaban, Iru, \& Asuru, 2019). The youth organization's role is very important as a platform for gathering young people in an attempt to carry out the organization's work in favor of the goals of establishing a just, stable, physically and mentally healthy state of Indonesia (Saputra, 2017).

The new face of youth is the hope of leading the Youth Law because the previous laws and regulations only led to the mindset that youth are only spectators of development. Youth should be a stimulus for national development. In the field of global youth studies, Dan Woodman and his colleague, Johanna Wyn from Melbourne University, Australia, are well-known youth studies experts from a social generation viewpoint, while Andy Bennett from Griffith University , Australia, is a young culture expert who is famous for the post-subculture concept (Oki Rahadianto, 2017a). Youth has the same capacity and position in development, just how to involve youth in the same position and position as decision making in managing good development from village to city. This expectation is increasingly exciting when a combination of the principles of recognition and subsidiarity emerges as the main principle that becomes the spirit of this Law. Also it is focused on the role of youth in all aspects of national development as contained in RI Law No. 40 of 2009 on Youth which reads youth plays an active role as a moral power, social influence and agent of change (Sanusi \& Darmawan, 2016). So, youth is a moral force, social control and agent of change in the process of nation-building, as a manifestation of its strategic function, role, characteristics and position in national development (Rahel Tomboku, 2009).

In 2009, the Ministry of Youth and Sports (Kemenpora) presented an objectively considered data on the existence of youth in Indonesia. Youth development policy is strategic in order to realize the enhancement of the quality of Indonesian human capital with the aim of achieving the goals of youth growth, namely the building of character, capacity building and youth competitiveness, as well as the creation of a fit, safe Indonesian community and its achievement (Sudirman et al., 2018). The data explains an indisputable fact that today's youth is also part of the nation's development problems. Technology unique to youth in this case definitely requires the cooperation of other parties.

Supporting groups can assist with youth character growth (Kusuma \& Jamanie, 2019). But referring to the view of Abdullah (1974), more able to take several reasons why youth should be responsible in the social fabric a. The purity of idealism; b. His courage and openness in absorbing new values and ownership-leadership; c. The spirit of devotion; d. Spontaneity and service; e. Innovation and creativity; f. Hope to immediately realize new vision-motivation; $g$. The firmness of its promises and the desire to display its independent attitude and personality; $h$. There are still scarce experiences that can be relevant opinions, attitudes, and actions with existing challenges. Like Pelopor's Youth, is a young man who has a passion for improving his ability to pave the way, make a difference, respond to challenges and provide solutions to different problems based on the attitude and spirit of voluntary work, duty and exception to produce something and/or turn ideas of thinking, action and actions into a consistent and enduring, meaningful quality work (Rahmawati, Maulana Haryadi, \& Soebagja, 2018).

Youth 's position and participation today has not shown full results in the pre- and postindependence periods relative to youth (Widiatmaka, P., Pramusinto, A., 2016). At present the role of the youth who are expected to be able to change the conditions of the war is not yet in line with what we expected, the barrenness of world civilization cannot be separated from the support of the role and position of youth as part of civilization. Youth is no longer able to play its role as a wall of civilization. Youth are ensnared in a system of pseudo-cultural hedonism, which takes away its human values. In the context of juvenile culture, the ties between social classes and subcultures of young people as developed by the Birmingham School may still be important (Oki Rahadianto, 2017b). The mindset that replaces pragmaticism with material transferred 
from the value of self-identity as a teacher of civilization. The position of youth can no longer be a supporter and motor in national development, but instead becomes a source of problems for civilization. A simple example of the problem that afflicts young people is illegal drugs. As a note, research has been carried out by the National Narcotics Agency (BNN) found that the number of drug users in Indonesia is around 3.8 million (BNN Data 2011) and 50 - 60 percent of drug users in Indonesia are among students and students. If the assumptions used are that the youth is like two sides of a blade that can have a positive effect on the one hand, and on the other hand it can have a negative effect, the presence of youth in the city of Medan becomes very vulnerable due to the disorientation of the function of the youth itself. Then there will be criminal acts, crimes and so forth.

North Sumatra experienced a decline in youth development, as captured through the Youth Development Index (IPP). In 2015, the provincial IPP was still 51 points. In that year, this index was even greater than three points above the national index. However, a year later the situation was reversed, the province's IPP declined to a level lower than 50, while the national IPP rose above the index 50. A rather special policy seems to be needed in increasing youth development in the city of Medan, due to a relatively deep decline. Of the four provinces that face a decline in youth development performance together with Central Kalimantan, Riau Islands, Bali and North Sumatra, including the deepest.

Whereas in the category of Kota Layak Pemuda (KLP) held by the Ministry of Youth and Sports in 2017 with consideration of several domains such as the quality of Education, health and welfare, employment and leadership participation, giving awards to 10 districts / cities that have decent youth resources, namely, District Bantaeng (South Sulawesi), Bandung City (West Java), North Jakarta City (DKI Jakarta), Makassar City (South Sulawesi), Padang City (West Sumatra), Tangerang City (Banten), Ternate City (North Maluku), Banda City Aceh (Aceh), Pontianak City (West Kalimantan), and South Tangerang City (Banten). Medan City is not included in the 10 decent cities of youth, this is proof of the low condition of participation and participation of youth in religious, social, cultural and economic development, in accordance with Nawa Cita and the commitment of the government, the world community in creating a district / city that has development system based on service and youth.

The generation perspective sees that the category as youth is rational and is the result of social construction, in other words each generation is always related to other words every generation is always related to the sociohistorical, economic and political context that houses it (Oki Rahadianto, Maika, Bennet, \& Efianingrum, 2014). The issuance of Law No. 40 of 2009 is an important discourse in the framework of excellent public services, and as a legal basis relating to youth development especially in the City of Medan. Related to regional development, the development model that used to be a Government driven development system should now lead to Community driven development that places youth as the executor of development programs from the government. In this way collaboration between the government and the involvement of youth will be able to realize national development, to empower the community in full.

Youth development is an important agenda that is the government's concern in building the nation. Youth is no longer an object but the subject of development with a facilitation, emancipation and consolidation approach. And now this is done using the imposition approach, unlike before using a multi-sectoral approach. The generational incentive, if followed, would be a tool for young people who have competition, profit and become a "sound" for youth development by creating youth as agents of change, social influence, pioneers of change, role models and leaders (Ariyadi, 2019).

Communication in an organization is considered important in terms of implementing policies because it provides understanding, equating perceptions and views of a problem, in order to achieve the goals of the organization and changes in the communicant 's behavior (Putu Eka Suadnyana \& Suksma Yogiswari, 2013). To analyze how the process of implementing development policies and youth empowerment takes place it can be seen from various models of policy implementation. We can find many views on the model (theory) of policy implementation in various policy concepts.

In conducting research on the Implementation of Youth Development Policy Programs by the Medan Municipality Youth and Sports Office (Dispora), the model of policy implementation 
that researchers used was the Policy Implementation Model from Edward III (Riant Nugroho, 2012). Edward III named his model of public policy implementation with the terms Direct and Indirect Impacts on implementation. Associated with theorized by Edward III, there are four variables that strongly agree on policy implementation, namely:

a. The communication process in implementing policies, both to the public and to fellow policy implementers or policy actors.

b. The state or availability of resources supporting the implementation of policies that affect the success of policy implementation

c. The process of approaching the implementation of policies through dispositions or attitudes of policy implementers

d. The process of forming or the availability of a bureaucratic structure as a support in the distribution of tasks and functions in implementing policies and compiling standard procedures.

The Commonwealth (2013) defines youth empowerment as an effort to "improve the status of youth, empower them to build their competence and ability to live their lives. This will enable youth to contribute and benefit from a stable political situation, a decent economic situation, and a supportive legal situation, which allows youth to fully participate as active citizens in their respective countries. "These definitions show that youth development includes a variety of domains or dimensions that need to be adequately addressed by sector policies or relevant ministries in the country. The birth of the precident regulation (peraturan presiden/Perpres) Number 66 of 2017 concerning Cross-Sector Strategic Coordination for the Implementation of Youth Services marks a new era of cross-cutting youth development. One of the mandates of the Perpres is to increase the capacity of youth in the aspect of development as a form of commitment in implementing Law No. 40 of 2009 (Kemenpora, in the 2017 IPP report). Various public policies and derivative programs formulated by the government play an important role in achieving the desired youth development goals. All policies provide direction to stakeholders about their respective roles and contribute to providing the necessary resources. The above statistics demonstrate that young people hold a very strategic role which can produce remarkable things like revolutionary changes (Hartati \& Murtasidin, 2018).

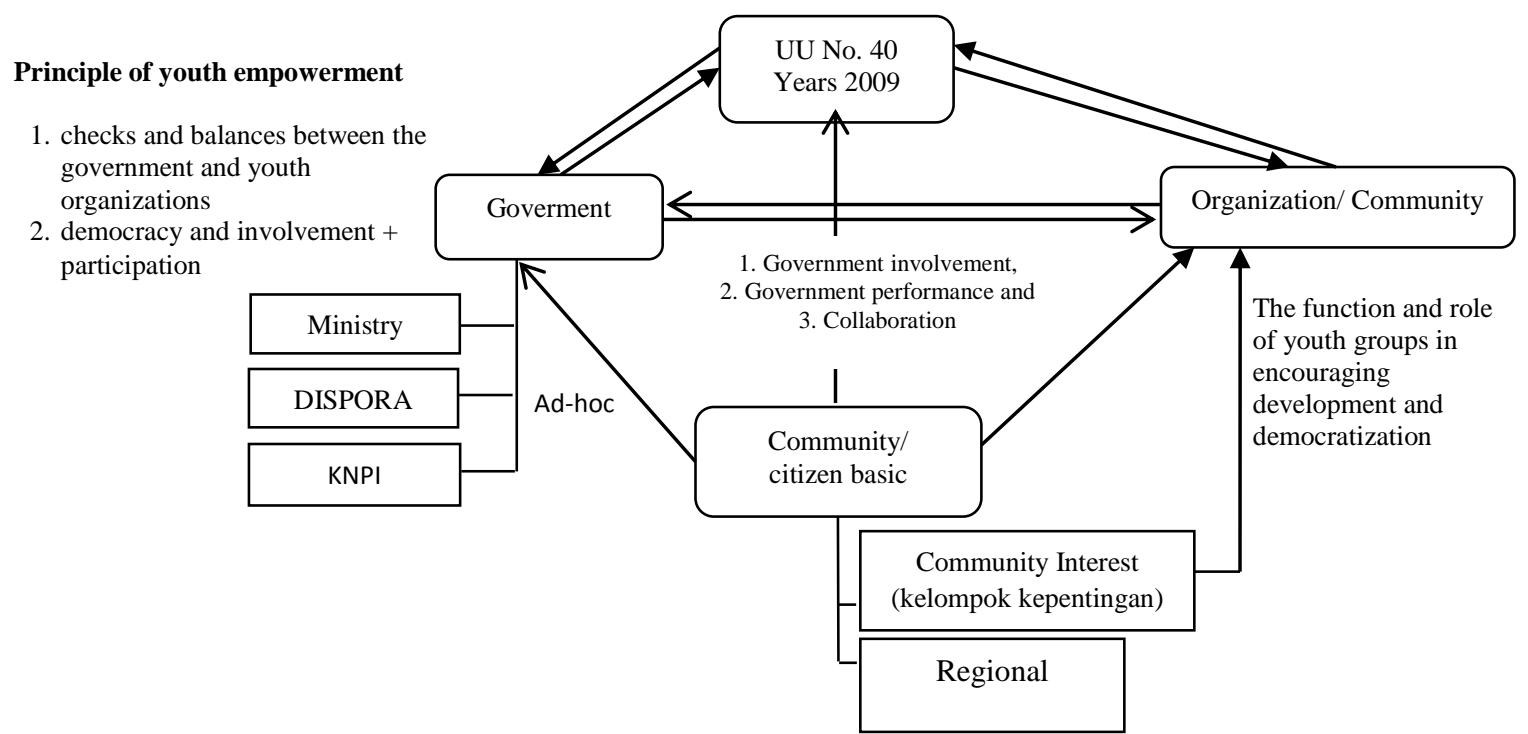

Figure.1

Youth empowerment system and collaborative order Source: Author, 2019

In figure. 1 shows to be able produce maximum development besides the decision of the central government in carrying out the functions of government administrators, the need for collaborative relationships involving youth as part of development requires three active roles of these elements including: 
1. The role of the government, both the central government and its devices (ministries) that can:

a) Managing community resources (Youth) for community needs.

b) Formulate well the needs of the community and plan according to the scale of priority development.

c) Increased ability to implement regional regulations and regulations regarding youth and their derivatives.

d) Manage development budgets with the principles of participatory, transparent and accountability.

2. The role of youth organizations and communities must be able to increase capacity in developing development plans, together with the government. This can be done by:

a) Strengthen participation by inviting citizens to be active in development activities.

b) Grow community initiatives to participate in developing development programs.

c) Communicating with the community and socialization related to development. It is not good enough or that the reach of communication between the government and the community has led to the lack of access to information related to development to the regions so that there is limited coordination in the implementation of development.

d) Carry out social values, mutual cooperation and consultation in decision making.

3. The role of the community that is active in development.

Encouraging the self-help movement in the formulation of regulations and supervision of development, because the community is the subject of policy regulation in the development itself.

\section{RESEARCH METHOD}

This study uses a type of qualitative descriptive research, which describes in full, detailed, clear and systematic and see whether the laws made by the Government can be carried out in accordance with the provisions or not. In this study I will examine whether Law Number 40 of 2009 concerning youth and how the role of Dispora in Medan municipality in implementing Law No. 40 of 2009 in accordance with the provisions or not. While the design of this study is intensive research case studies on certain organizations, institutions or symptoms with or limited but deep area coverage. The research subject is reflected in the focus of this deliberately determined study, the subject will be the respondent who provides the information and information needed. Key informants in accordance with this research technique are the Head of the Department of Youth and Sports of Medan City as Ex-Officio, Head of the Dispora Improvement Division of Medan City, and Head of Youth Dispora in Medan municipality. This informant is also called a key informant. In addition, to enrich information, several other sources such as youth organizations, student organizations will also become respondents. They are often referred to as additional informants.

\section{RESULT AND DICUSSION \\ Implementation of Law No. 40 of 2009 concerning Youth Development Policy in Medan Municipality}

\section{Legal Basis for Implementation of Law No. 40 of 2009 concerning Youth Development Policy in Medan Municipality}

The implementation of Law No. 40 of 2009 concerning youth in Medan City began with the issuance of Presidential Regulation No. 57 of 2015 concerning the Ministry of Youth and Sports. Based on the president's direction according to article 3 paragraph a and b of Law No. 57 of 2015, namely:

Paragraph a:

"The need for the formulation and stipulation of policies in the fields of youth empowerment, youth development, sports culture, and increasing sports achievements" 
Paragraph b:

"Coordination and synchronization of the implementation of policies in the field of youth empowerment, youth development, civilizing sports, and improving sports achievements"

Based on Peraturan Presiden (Perpres) Number 66 of 2017 concerning Cross-Sector Strategic Coordination of Youth Service Implementation regarding cross-cutting youth development, collaboration systems between the central government to local governments and youth organizations is to organize youth services that are in accordance with the development goals of Nawacita.

Based on the results of the research conducted, it can be concluded that the Medan City Government through the Dispora in carrying out the mandate of Law No. 40 of 2009 does not yet have a clear reference in youth development policies, where in the implementation of the application of service principles in youth development there is no strong basic law. If legal products in the form of regional regulations and mayor regulations as guidelines for the Medan Municipality in implementing the Youth Law do not yet exist, this proves that in implementing youth empowerment and capacity building in supporting development, the city government of Medan does not have seriousness and commitment in the process of implementing the law.

Based on the findings of the researchers, the basic implementation of the policy is only limited to the formulation of the youth empowerment agenda in the Local government regulation (Perda) of Medan City No. 8 of 2009 concerning the Medan City Long-Term Development Plan for 2006-2025 and Medan City Regulation Number 14 of 2011 concerning the Medan Regional Medium-Term Development Plan for 2011-2015. The policies formulated by Pemko Medan are still generally regulated in the Perda relating to the long term development planand (RPJP) and medium term development plan (RPJM) of Medan City.

It can be concluded that the lack of seriousness in the commitment of the Medan City government in the development of the Medan municipality youth must issue a Regional Regulation (Perda) as a guideline to implement youth empowerment. Because the need for regulations that have operational standards to increase the capacity of youth in development aspects as a form of commitment in implementing Law No. 40 of 2009.

\section{Targets for the Implementation of Law No. 40 of 2009 concerning Youth Development Policy in Medan City}

According to George Edward III the determination of policy targets is influenced by how the implementor is able to provide content and policy objectives properly. Implementation of this policy will produce output and where the output is the perceived impact of policy objectives from policy implementation and the result is the impact felt by those targeted in this policy. Based on the findings of Medan Municipality researchers as the leading sector in youth development in the city of Medan, they have carried out their duties despite the legal basis in the form of RPJP and RPJMD Pemko Medan.

Vision of the Dispora of the Medan Municipality in accordance with the RPJMD for 20112015 formulates a vision relating to "Resilient Youth and Races and the City of Sports." Based on this vision a number of missions are arranged, namely:

1. Improve youth and sports facilities and infrastructure in Medan City;

2. Increasing the development and development of youth and sports activities in Medan City;

3. Fostering and improving the welfare of sportsmen in the future.

Through the mission stated above, it can then be seen the goals and objectives of the Medan City youth development policy through Dispora, namely:

1. The aim of improving youth and sports facilities and infrastructure, with the following objectives:

a. Increased number of centers / youth centers (other than private property)

b. per thousand population in to 4;

c. Increasing the ratio of sports fields per thousand population in to 30 ;

d. Increased number of sports clubs per ten thousand residents in to 6.25;

e. Increasing the number of sports buildings per ten thousand residents in to 0.085 ; 
2. Increasing the participation and role of youth in urban development, with the following objectives:

a. Increased participation and participation of youth in urban development;

b. The increasing number of youth activities in to 16;

3. Improving culture and sports achievements, with the following objectives:

a. Increased sports culture in the community;

b. Increased sports achievements at regional, national and international levels;

c. The increasing number of sports activities in to 36 ;

Based on the data above the program listed in the vision and mission of the Dispora of Medan City is still dominated by sports programs and is not focused on fostering youth groups incorporated in youth organizations. In terms of empowering young people, these conditions can be considered not on target because they do not refer to the conditions of youth objectives in the city of Medan.

Table.1 List of Program Activities of DISPORA Medan City Realization in 2016-2019

\begin{tabular}{|c|c|c|c|c|c|c|c|c|c|}
\hline \multirow{2}{*}{ No } & \multirow{2}{*}{ Program And Activity } & \multicolumn{4}{|c|}{$\begin{array}{c}\text { Year } \\
\text { Implementation }\end{array}$} & \multicolumn{2}{|c|}{$\begin{array}{c}\text { Realization of } \\
\text { Activities }\end{array}$} & \multicolumn{2}{|c|}{$\begin{array}{l}\text { Follow } \\
\text { Up } \\
\text { Activity }\end{array}$} \\
\hline & & 2015 & 2016 & 2017 & 2019 & $\begin{array}{c}\text { Realize } \\
\text { d }\end{array}$ & $\begin{array}{c}\text { Not } \\
\text { Realize } \\
\text { d }\end{array}$ & Exist & $\begin{array}{l}\text { Not } \\
\text { exis } \\
t\end{array}$ \\
\hline \multirow[t]{5}{*}{1} & $\begin{array}{l}\text { Development Program } \\
\text { an Youth Policy } \\
\text { Harmony }\end{array}$ & & & & & & & & \\
\hline & $\begin{array}{l}\text { Development Expansion } \\
\text { Activities Regional Field } \\
\text { Action Plan Youth }\end{array}$ & - & - & - & - & - & - & - & $\mathrm{v}$ \\
\hline & Youth Profiling & - & - & $\mathrm{V}$ & $\mathrm{v}$ & - & $\mathrm{v}$ & - & $\mathrm{v}$ \\
\hline & $\begin{array}{l}\text { Strengthening Moral } \\
\text { Capacity and Youth } \\
\text { Independence Intellectual }\end{array}$ & - & - & - & - & - & $\mathrm{v}$ & - & $\mathrm{v}$ \\
\hline & $\begin{array}{l}\text { Youth Capacity Building } \\
\text { Cross Religion }\end{array}$ & - & - & - & - & - & $\mathrm{v}$ & - & $\mathrm{v}$ \\
\hline \multirow[t]{7}{*}{2} & $\begin{array}{l}\text { Participatory } \\
\text { Improvement Program } \\
\text { Youth }\end{array}$ & & & & & & & & \\
\hline & $\begin{array}{l}\text { Youth Organization } \\
\text { Development, Basic } \\
\text { Education and Training } \\
\text { Leadership } \\
\text { Jamboree and Bhakti }\end{array}$ & - & - & $\mathrm{v}$ & $\mathrm{v}$ & - & $\mathrm{v}$ & - & $\mathrm{v}$ \\
\hline & $\begin{array}{l}\text { Pemuda Antar Districts / } \\
\text { Cities in the city of Medan } \\
\text { Candidates for Youth }\end{array}$ & - & - & $\mathrm{v}$ & - & - & $\mathrm{v}$ & - & $\mathrm{v}$ \\
\hline & $\begin{array}{l}\text { Exchange Candidates } \\
\text { Between countries }\end{array}$ & $\mathrm{v}$ & $\mathrm{v}$ & $\mathrm{v}$ & $\mathrm{v}$ & $\mathrm{v}$ & - & $\mathrm{V}$ & - \\
\hline & $\begin{array}{l}\text { Management Training and } \\
\text { Leadership for } \\
\text { Management Youth } \\
\text { Organization }\end{array}$ & - & $\mathrm{v}$ & - & $\mathrm{v}$ & - & $\mathrm{v}$ & - & $\mathrm{V}$ \\
\hline & $\begin{array}{l}\text { National Resilience } \\
\text { TrainingYouth }\end{array}$ & - & - & - & - & - & $\mathrm{v}$ & - & $\mathrm{v}$ \\
\hline & $\begin{array}{l}\text { Coaching Trainers / } \\
\text { Facilitators Training } \\
\text { Indonesian volunteers }\end{array}$ & - & - & $\mathrm{v}$ & - & - & $\mathrm{v}$ & - & $\mathrm{v}$ \\
\hline 144 & & & & Darm & ristian $\mathrm{F}$ & dede, JGP & ol.7, No & 020): J & 2020 \\
\hline
\end{tabular}




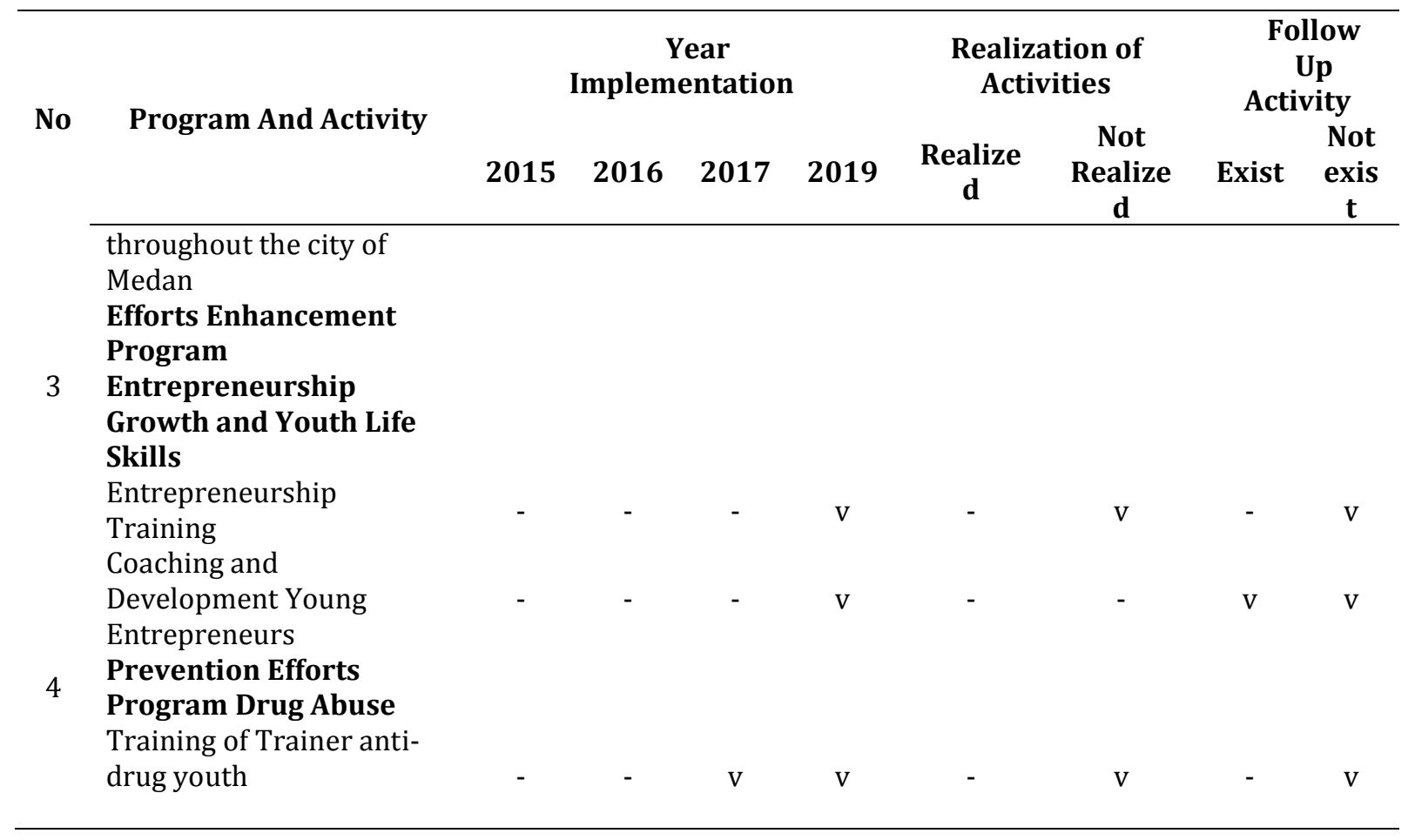

From table. 1 above, there are a number of different forms and names of activities and the realization of the year of implementation. This is caused by limitations (or changes) in the budget (APBD) of the Medan Municipality. Implementation of youth programs that have been implemented, then the authors measure the level of effectiveness through three indicators. First, in terms of the source approach. Second, in terms of the process approach. And third, in terms of the goals approach.

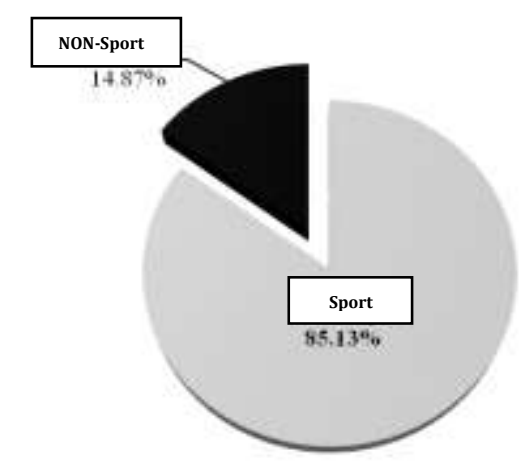

Figure.2

Comparison of Youth Budgets in Sports and Non-sports.

Source: Processed from Dispora Strategic Plan Data Medan Municipality in 2016-2019

While based on the figure. 2 above, it can be seen that in reality the youth development budget within the Medan City Government policy framework still relies on the sport sector only. It can be seen that the sports sector occupies a sizable percentage, especially in the aspects of facilities and infrastructure as well as sports development and correctional facilities, even for facilities and infrastructure alone reaching $64.84 \%$. While youth development outside sports, on average is under $5 \%$, only youth participation programs reach $8.16 \%$.

The purpose of the implementation of Law No. 40 of 2009 still leads to the development of special fields, namely sports. As stated by the Chairperson of Medan City KNPI. El Adrianshah, SE. As the head of the youth committee, he saw programs organized by the Dispora of Medan City not on target because increasing youth capacity must be collaborative where the government is a 
supporting system in supporting the needs of youth according to the characteristics of youth in the community or organization where they are.

\section{Implementation Objective Act No. 14 Year 2008 on concerning Youth Development Policy in Medan Municipality in Medan Municipality government}

\section{Communication}

The success of the implementation of the policy implies that the implementor knows what must be done and what is the purpose and target of the group so that the implementation can actually run and if the goals and objectives are not known then resistance will emerge from the target group. The need for coordination between implementors or implementers of policies will form a systematic system of work so that youth development will be realized. In George Edward III's theory which supports the implementation of a policy if a policy is transmitted well or has clarity of goals and objectives of the group, there is consistency given by the implementing policy. If what is communicated changes will be confusing in the implementation of the policy in question.

Based on research, Dispora Medan Municiplity has run and has been understood by implementing agencies well seen from the understanding of informants about the objectives of policies, tasks, functions and authorities in understanding the contents of the mandate of Law No. 40 of 2009. But the weak commitment shown by Dispora can be seen from lack of understanding of program formulation in accordance with the characteristics of the needs of youth in the city of Medan. If referring to the information conveyed by the Head of Youth in the Dispora of Medan Municipality, Mr. Suryadi, SE., MM., targets related to the needs of individuals and organizational groups in Dispora programs, are often limited in terms of budget. If it concerns the needs of the organization according to its explanation, Youth Organization (OKP) groups must communicate with Dispora in terms of collaborative programs that are in accordance with the organization.

It is different from the opinions of the youth who were organized by students as stated by Swangro Lumbanbatu as the Coordinator of the North Sumatera-Aceh GMKI region for the period of 2016-2018 who concluded that there were still many youth and student organizations in Indonesia, especially in Medan city in weak conditions so many young people are no longer organized. This was caused aside from internal organizational factors but also due to the inaccurate target of the Dispora program due to lack of coordination between North Sumatra and Medan Dispora with student groups, especially Kelompok Cipayung which when viewed from organizational characteristics were cadre organizations so Pemko Medan should be able to facilitate the Organization capacity building and upgrading, training for members both in budget facilities and supporting infrastructure.

This was also affirmed by the Chairperson of the Medan Branch of the Indonesian National Student Movement (GMNI) Maman Silaban who stated that there was a lack of communication between organizations with theDispora Pemko Medan regarding the Budget in fostering members for each organization. Because coaching is the initial capital in empowering young people in every aspect of development.

\section{Policy Facilities and Resources}

According to George Edward III, the determination of policy targets is influenced by how the Resource implementor is able to provide content and policy objectives well. Implementation of this policy will produce outputs and outcomes where the output is the perceived impact of the policy objectives of the policy implementation and the outcome is the impact felt by those who are not targeted in this policy.

In the implementation of policies on the completeness of policies on facilities and resources it functions as a supporter of the implementation of administrative implementation where the formation of a flow of good performance. Therefore, in implementing this policy, we need facilities and infrastructure that are important for the realization of increasing the capacity of youth to support development. Based on the Dispora vision and mission of Medan City, the policy focuses on improving character through mental strengthening in the field of sports. In order to optimize the implementation of coaching and improvement in sports achievements, the 
City Government has a commitment in terms of budgeting in the field of youth and sports. Youth and sports budgets must be prioritized for efforts to foster and increase sports performance, as well as in the framework of sports socialization (Pemko Medan, 2011).

In this case the Pemko Medan has provided a sports center and several other sports facilities.

Based on the explanation of the City of Medan RPJMD in 2011-2015 related to the comparison of budget allocations in the fields of sports and non-sports, it can be seen in fact that the budget allocated according to the Medan Municiplity policy is still based on the sports sector. It can be seen that the sports sector occupies a fairly large percentage, especially in the aspects of facilities and infrastructure as well as training and socialization of sports, even for facilities and infrastructure alone reaching $64.84 \%$. While youth development outside the sport, on average, is below $5 \%$, only the youth participation program reaches $8.16 \%$. But regarding the facilities and infrastructure for youth organizations and Dispora students have prepared a budget in training and education for organizations. So it can be said that the optimization of the means of supporting prasara has not been evenly distributed.

\section{Disposition/Attitudes of Implementing Agents}

In the theory of policy implementation according to George Edward III the attitude or implementing disposition is divided into three things, namely; (A). Commitment, (b). Honesty, and (c). Democratic attitude. Understanding this position is very important to see what the implementer must respond to. Understanding the implementation of the policies that will be implemented encourages the attitude of the implementers to support or reject the implementation of the policy as well as the responses given to the readiness of benchmarks from the implementers of their own policies to implement a policy.

Based on the findings in the field of disposition or the attitude of the implementing agency shown very well seen from the Dispora commitment of the Medan City Government in guiding youth in the city of Medan, other things were also shown by the involvement of youth organizations in technical meetings even though they did not participate in the policy formulation of youth participation in development. However, to strengthen the attachment and role of each institution, it is necessary to improve communication patterns of commitment as a manifestation of the program formulation and implementation.

\section{Bureaucratic Strukture}

George Edward III explains that the organization provides a simple map to show its general activity and the distance from the peak shows its relative status. The lines between various positions are framed to show the formal interactions that are applied. A clear bureaucratic structure will support the implementation of youth development policies, a clear structure influencing the division of tasks and responsibilities in each section can be implemented properly. In addition, in implementing policies each person in their respective fields is bound by the norms or values of the prevailing work environment. Implementation of Law No. 40 of 2009 concerning youth development and how the role of the city government in youth development has a clear organizational structure. Although the Medan Municipality has quite a number of Regional Work Units (SKPD) and allows for youth development programs, in matters that are more focused when tracking data in the field, this program is always directed to the Department of Youth and Sports (Dispora). Based on the findings and interviews with resource persons, the relationship between one work units is very important and regulated in the existing operational standard regulations (SOP). The structure is in the form of the Head of the Youth and Sports department as Ex-Officio and assisted by the youth empowerment sector and the field of sports performance improvement. The level of managerial position hierarchy shows who is responsible for youth development in Medan Municipality, but each of the parties involved in this case the apparatus, youth organizations and regional governments have not been competent enough in carrying out the tasks assigned to them, especially in realizing cities worthy of youth (KLP) 


\section{CONCLUSION}

Since the enactment of these laws and regulations up to now the implementation has not run optimally and in accordance with the rules and Standard Operating Procedures (SOP) set by the Dispora. This is due to lack of funding, lack of information received by youth organizations / communities so that supervision of development is lacking, provision of facilities and facilities and supporting policies have not been able to guarantee the quality of youth development. Based on the description of the results and discussion described in the previous chapter regarding the role of the Medan Municipality in youth development policies In accordance with Law No. 40 of 2009 and Managing Perpres No. 66 of 2017 concerning Cross-Sectoral Policies in the Implementation of Youth Services and collaboration systems for youth development, it can be withdrawn conclusion: Implementation of Law Number 40 of 2009 in the City Government of Medan has not shown a serious commitment where there is no legal product or legal umbrella in the form of regulation of Mayor (Perwal) which is strong in its commitment to the implementation of Youth Development and empowerment in supporting Development. The Pemko Medan policy in the aspect of youth development is the leading sector of the Department of Youth and Sports as an SKPD which is responsible for youth and sports. It is necessary to form a Peraturan walikota (Perwal) or Peraturan daerah (Perda) in focusing youth as objects of development rather than being subject to development. On the other hand, the program compiled by the Dispora is still in the general aspects described in the RPJMD of Medan Municipality. Dispora in Medan must have a long-term program design in determining youth empowerment and involvement variables in development aspects, especially in the formulation of policies related to training facilities and infrastructure, development and budget for youth empowerment not only focusing on the sports sector. Regarding the attitudes and dispositions of the implementing agency, it has not shown a good trend in realizing youth who are empowered to support the development of Medan as a City Worthy of Youth (Kota Layak Pemuda)

\section{REFERENCE}

Abdullah, Taufik., Pemuda dan Perubahan Sosial. Jakarta: LP3ES, 1974.

Ariyadi, F. (2019). Analisis Implementasi Kebijakan Pemberdayaan Pemuda Melalui Program Jambore Pemuda Indonesia (Jpi) Dalam Pembangunan Kepemudaan Di Provinsi Kalimantan Timur. Jurnal Administrative Reform, 7(2), 64-72.

Hartati, S., \& Murtasidin, B. (2018). Efektivitas Pembangunan Kepemudaan Di Provinsi Riau Tahun 2014-2016 (Studi Kasus Pada Dinas Kepemudaan Dan Olahraga). Jurnl Dinamika Pemerintahan, 2(2), 110-126.

Kementerian Pemuda dan Olahraga, Penyajian Data dan Informasi Kementerian Pemuda dan Olahraga Tahun 2009. (Jakarta: Biro Perencanaan Kemenpora, 2009)

Kartasasmita, Ginanjar, Administrasi Pembangunan, Jakarta: LP3ES, 1997.

Kusuma, A. R., \& Jamanie, F. (2019). Implementasi Peraturan Pemerintah Nomor 41 Tahun 2011 Tentang Pengembangan Kepeloporan Pemuda Di. EJournal Administrative Reform, 7(2), 219-231.

Nugroho, Riant. 2012. Public Policy: Dinamika Kebijakan, Analisi Kebijakan dan Manajemen Kebijakan Jakarta: Penerbit PT Elex Media Komputindo.

Oki Rahadianto, S. (2017a). Menjembatani Perspektif Budaya dan Perspektif Transisi dalam Kajian Kepemudaan. MASYARAKAT: Jurnal Sosiologi, 22(1), 133-138. https://doi.org/10.7454/mjs.v22i1.8059

Oki Rahadianto, S. (2017b). Menjembatani Perspektif Budaya dan Perspektif Transisi dalam Kajian Kepemudaan. MASYARAKAT: Jurnal Sosiologi, 22(1). https://doi.org/10.7454/mjs.v22i1.8059

Oki Rahadianto, S., Maika, A., Bennet, A., \& Efianingrum, A. (2014). Perspektif Generasi dalam Kajian kepemudaan (First). Yogyakarta: P2MPS.

Pemko Medan, Rencana Pembangunan Jangka Meengah Daerah Kota Medan Tahun 2011-2015. (Medan: Pemko Medan, 2011).

Pemko Medan, Rencana Pembangunan Jangka Pajang Kota Medan Tahun 2016-2025. (Medan: Pemko Medan, 2009). 
Putu Eka Suadnyana, I. B., \& Suksma Yogiswari, K. (2013). Peranan Komunikasi Persuasif Dalam Implementasi Ajaran Tri Hita Karana Pada Sekaa Truna Truni. STAHN MPU Kuturan Singaraja, 53(9), 1689-1699. https://doi.org/10.1017/CB09781107415324.004

Rahel Tomboku, M. (2009). Implementasi Program Pelayanan Kepemudaan Pada Dinas Pemuda Dan Olahraga Propinsi Sulawesi Utara.

Rahmawati, R., Maulana Haryadi, W., \& Soebagja, O. (2018). Implementasi Program Kegiatan Pemuda Pelopor Pada Dinas Pemuda Dan Olahraga Kota Bogor. ADMINISTRATIE Jurnal Administrasi Publik, 1(September), 111-116.

Sanusi, A. R., \& Darmawan, C. (2016). Implementasi Pendidikan Politik dalam Membentuk Karakter Kepemimpinan Lintas Budaya pada Generasi Muda Demi Mewujudkan Budaya Politik Pancasila. Jurnal Pendidikan Ilmu Sosial, 25(1), 24-40. Retrieved from http://ejournal.upi.edu/index.php/jpis/article/view/3668/2620

Saputra, I. (2017). Peran Organisasi Kepemudaan Dalam Meningkatkan Pemahaman Wawasan Nusantara Di Kalangan Pemuda Indonesia. CIVIC-CULTURE" Jurnal Ilmu Pendidikan PKn Dan Sosial Budaya", 1(1), 33-41.

Sudirman, I., Aminawar, M., Alam, A. S., Sakharina, I. K., Darwis, M., \& Kurniawan, M. E. (2018). Kajian Strategi Kebijakan Pembangunan Kepemudaan di Kabupaten Luwu Utara. Jurnal Bangda Simpurusiang, 1(1), 19. https://doi.org/10.33297/jbs.v1i1.2018.61-80

Syaban, A., Iru, L., \& Asuru, A. (2019). Implementasi Kebijakan Pemerintah Daerah Di Bidang Pendidikan Non Formal Pada Anak Jalanan Di Kota Kendari. Selami IPS, 2, 1-476. https://doi.org/10.1017/CB09781107415324.004

Tjokromidjojo, Bintoro., Pengantar Administrasi Pembangunan. Jakarta: LP3ES. 1990.

Todaro, Michael, P., Pembangunan Ekonomi i Dunia Ketiga. Jakarta: Erlangga, 2000.

Widiatmaka, P., Pramusinto, A., \& K. (2016). Peran Organisasi Kepemudaan Dalam Membangun Karakter Pemuda Dan Implikasinya Terhadap Ketahanan Pribadi Pemuda (Studi Pada Pimpinan Cabang Gerakan Pemuda Ansor di Kabupaten Sukoharjo Provinsi Jawa Tengah ). Jurnal Ketahanan Nasional, 22(2), 180-198.

Walikota Medan. Perda No. 8 Tahun 2009 Tentang Rencana Pembangunan Jangka Panjang Kota Medan Tahun 2006-2025

Republik Indonesia. Undang-Undang Nomor 40 Tahun 2009 tentang Kepemudaan

Presiden Repiblik Indonesia. Peraturan Presiden No 57 tahun 2015 tentang Kementerin Pemuda dan Olahraga

Presiden Republik Indonesia. Peraturan Presiden (Perpres) Nomor 66 Tahun 2017 tentang Koordinasi Strategis Lintas Sektor Penyelenggaraan Pelayanan Kepemudaan tentang system kolaborasi pembangunan kepemudaan 